\title{
Toxic Effects of Ethyl Cinnamate on the Photosynthesis and Physiological Characteristics of Chlorella vulgaris Based on Chlorophyll Fluorescence and Flow Cytometry Analysis
}

\author{
Yang Jiao, Hui-Ling Ouyang, Yu-Jiao Jiang, Xiang-Zhen Kong, Wei He, Wen-Xiu Liu, \\ Bin Yang, and Fu-Liu Xu \\ MOE Laboratory for Earth Surface Processes, College of Urban \& Environmental Sciences, Peking University, Beijing 100871, China \\ Correspondence should be addressed to Fu-Liu Xu; xufl@urban.pku.edu.cn
}

Received 29 January 2015; Revised 10 April 2015; Accepted 7 May 2015

Academic Editor: Huansheng Cao

Copyright (C) 2015 Yang Jiao et al. This is an open access article distributed under the Creative Commons Attribution License, which permits unrestricted use, distribution, and reproduction in any medium, provided the original work is properly cited.

\begin{abstract}
The toxic effects of ethyl cinnamate on the photosynthetic and physiological characteristics of Chlorella vulgaris were studied based on chlorophyll fluorescence and flow cytometry analysis. Parameters, including biomass, $F_{v} / F_{m}$ (maximal photochemical efficiency of PSII), $\Phi_{\text {PSII }}$ (actual photochemical efficiency of PSII in the light), FDA, and PI staining fluorescence, were measured. The results showed the following: (1) The inhibition on biomass increased as the exposure concentration increased. $1 \mathrm{mg} / \mathrm{L}$ ethyl cinnamate was sufficient to reduce the total biomass of $C$. vulgaris. The 48 -h and $72-\mathrm{h}$ EC50 values were $2.07 \mathrm{mg} / \mathrm{L}(1.94-2.20) \mathrm{and} 1.89 \mathrm{mg} / \mathrm{L}$ (1.82-1.97). (2) After $24 \mathrm{~h}$ of exposure to $2-4 \mathrm{mg} / \mathrm{L}$ ethyl cinnamate, the photosynthesis of $C$. vulgaris almost ceased, manifesting in $\Phi_{\mathrm{PSII}}$ being close to zero. After $72 \mathrm{~h}$ of exposure to $4 \mathrm{mg} / \mathrm{L}$ ethyl cinnamate, the $F_{v} / F_{m}$ of $C$. vulgaris dropped to zero. (3) Ethyl cinnamate also affected the cellular physiology of C. vulgaris, but these effects resulted in the inhibition of cell yield rather than cell death. Exposure to ethyl cinnamate resulted in decreased esterase activities in C. vulgaris, increased average cell size, and altered intensities of chlorophyll a fluorescence. Overall, esterase activity was the most sensitive variable.
\end{abstract}

\section{Introduction}

Algae are the main primary producers in aquatic ecosystems and are often used as environmental quality indicators [1] and experimental species for aquatic ecotoxicological research $[2,3]$. Algal bloom is an important cause of the degradation of aquatic ecosystems in eutrophic water bodies [4]. Traditional chemical methods can effectively remove algae but can also cause secondary pollutions [5]. Meanwhile, traditional physical technology and biotechnology for bloom mitigation also have some disadvantages, such as long operating time, operating difficulty, and high costs [6]. In recent years, the use of allelochemicals to inhibit algal blooms has become a cost-effective method with broad application prospects [7].

Allelopathy was first introduced by Molisch in 1937 and it means that creatures, including microorganisms, exert a favorable or unfavorable influence on others through biochemical substances. Rice constrained allelopathy in his definition in 1979, holding the view that allelopathy merely meant that plants have adverse effects on other plants and the biochemical substances were released by organisms [8]. Studies have shown that allelopathy is ubiquitous in aquatic ecosystems and that almost all primary producers can produce and release allelochemicals [9]. For practical applications, there are generally three methods to inhibit algae using allelopathy of plants. (I) Cultivate aquatic plants in water and utilize the substances that are released by plants to inhibit algae. (II) Add dead plants into the water and utilize the substances that are released during the rot process to inhibit algae. (III) Add allelochemicals that have been extracted from plants into water [6].

In recent years, research on the utilization of allelochemicals to inhibit algae has become increasingly popular. Various allelochemicals have been extracted and identified, such as sesquiterpene lactones, organic acids, and phenols. Among these allelochemicals, phenolic acids (such as ethyl cinnamate) have strong activities [8-11]. Allelochemicals could affect many photosynthetic and physiological characteristics 
of algae, such as cell membrane permeability, reproduction, photosynthesis and respiration, protein synthesis, and resistance to diseases [12-20]. Allelochemicals affect algae selectively; therefore, different species of algae have varied inhibition responses [21-24].

Currently, research on allelopathy mainly focuses on aquatic plants and rarely on terrestrial plants, especially xylophyta. Compared with hydrophytes, terrestrial plants are more widely distributed. In addition, terrestrial plants are easy to cultivate, break, and process. Many species of herbage and xylophyta are rich in allelochemicals and, as a consequence, have better prospects in inhibiting algal blooms and the emergency response to algal blooms [25]. The allelochemicals that are produced and released by terrestrial plants can be washed from land into water by rain and interact with organisms in the water. Therefore, research on the allelochemicals, such as ethyl cinnamate, that are produced by terrestrial plants has more practical significance in inhibition of algae. However, current research on the effects of cinnamic acid and its derivatives on algal inhibition is still rare and mostly utilizes traditional methods of algal toxicology. Relevant research mainly focuses on the algal reproduction, the activities of algal antioxidant enzymes, the lipid peroxidation of cell membrane, and the interaction with nutrients such as $\mathrm{N}$ and $\mathrm{K}$ [26-29]. However, these traditional methods cannot distinguish between dead and living cells during cultivation, potentially causing variations that deviate from the real results [30]. In addition, traditional research methods of algal toxicity focus more on the toxicity of substances and less on the response of other algal physiological processes, such as photosynthesis. It is impossible to understand the mechanism of allelopathy comprehensively.

Chlorophyll fluorescence analysis and flow cytometry are new methods that have been used to study the photosynthetic toxicity and cytotoxicity of heavy metals and other pollutants on algae in recent years [2,3]. Chlorophyll fluorescence analysis is based on the photosynthetic theory, using chlorophyll fluorescence in vivo as a probe to study the photosynthetic physiological state of organisms under the influences of various external factors [31]. Chlorophyll fluorescence analysis is rapid and sensitive, and it can also detect the photosynthetic toxicity with no damage to algae [31-34]. Flow cytometry (FCM), an automated cell or biological particles analysis technique, is capable of rapid multiple parameter detections of a single cell and has been extensively used in algal toxicity studies in recent years [35-37]. Compared with traditional methods, flow cytometry is conducive to obtaining algal responses under stress conditions on cellular level. The application of flow cytometry allows for algal toxicological research on cellular level, and this technique contributes to understanding the action mechanism of toxins.

In this study, experiments were performed to study the toxic effects of ethyl cinnamate on Chlorella vulgaris, a dominant species of green algae. This study, based on traditional algal toxicological research methods, used chlorophyll fluorescence analysis and flow cytometry to study how ethyl cinnamate affected the growth, photosynthesis, and cell physiology of C. vulgaris, in order to understand the effects and the action mechanism of allelochemicals further.

\section{Materials and Methods}

\subsection{Experimental Materials}

2.1.1. Algal Strain. In this study, Chlorella vulgaris was selected as algal material for its two advantages. C. vulgaris requires relatively simple growth conditions and has a strong environmental tolerance and a high reproductive rate. In addition, many domestic and overseas researchers have also selected C. vulgaris as test algal material [38], which makes comparing results convenient. C. vulgaris was purchased from the Freshwater Algae Culture Collection of the Institute of Hydrobiology, Chinese Academy of Sciences.

2.1.2. Chemical Materials. Ethyl cinnamate (99.1\% purity) was purchased from Alfa Aesar (America) and used in exposure experiments of Chlorella vulgaris. Dimethyl sulfoxide (analytical grade) was purchased from Beijing Chemical Works (China) for the solubilization of ethyl cinnamate. Main components in BG11 medium were all purchased from Sinopharm Chemical Reagent Co., Ltd. (China) for cultivation of $C$. vulgaris. Fluorescein diacetate (FDA) was purchased from Sigma (America) for staining algal cells in flow cytometric analysis. Acetone was purchased from Beijing Chemical Works (China) for the solubilization of FDA. Propidium iodide (PI) was purchased from Sigma (America) for staining algal cells in flow cytometric analysis.

\subsection{Experimental Methods}

\subsubsection{Experimental Conditions}

(1) Algal Culture Conditions. Chlorella vulgaris was cultivated in BG11 medium at $24 \pm 1^{\circ} \mathrm{C}$ with a cycle of light $(14 \mathrm{~h}$, 4000 Lux) and dark (10 h, 0 Lux) in a GXZ-280B illumination cultivation cabinet (China). C. vulgaris was cultivated statically and was not aerated during the cultivation. The cultures were shaken two to three times daily and their positions were changed randomly.

(2) Exposure Experiments. Chlorella vulgaris was cultivated in $50 \mathrm{~mL}$ BG11 medium in 150-mL Erlenmeyer flasks (the initial cell density of C. vulgaris was approximately $2 \times$ $10^{6}$ cells $/ \mathrm{mL}$ ). C. vulgaris was exposed to ethyl cinnamate at final total concentrations of $0.5 \mathrm{mg} / \mathrm{L}, 1 \mathrm{mg} / \mathrm{L}, 2 \mathrm{mg} / \mathrm{L}, 3 \mathrm{mg} / \mathrm{L}$, and $4 \mathrm{mg} / \mathrm{L}$ for $96 \mathrm{~h}$. In the experiment, $0.1 \mathrm{~mL}$ dimethyl sulfoxide was added to each sample $(50 \mathrm{~mL}$ in total) for the solubilization of ethyl cinnamate. Preliminary results showed that $0.2 \%$ dimethyl sulfoxide $(0.1 \mathrm{~mL}$ in $50 \mathrm{~mL}$ medium $)$ had no significant impact on the photosynthetic and physiological characteristics in C. vulgaris. Exposure tests and controls were set up in triplicate. The biomass, chlorophyll fluorescence, and flow cytometry were measured every $24 \mathrm{~h}$ during the experiments.

\subsubsection{Measurements of the Indicators}

(1) Biomass Analysis. Optical density of algal samples at $450 \mathrm{~nm}$ correlated with algal cell density determined by 
hemocytometer $\left(\right.$ cell density $\left(10^{6}\right.$ cells $\left./ \mathrm{mL}\right)=27.6 \times$ OD450 and $R^{2}=0.9994$ ). Therefore, biomass was obtained by measuring the optical density of algal samples at $450 \mathrm{~nm}$ using a microplate reader (Model-680, Bio-Rad). The growth inhibition rate $\left(P_{1}\right)$ of Chlorella vulgaris was calculated using

$$
P_{1}=\frac{N_{\text {tcontrol }}-N_{\text {ttreatment }}}{N_{\text {tcontrol }}-N_{0}}
$$

In formula (1), $N_{\text {tcontrol }}$ and $N_{\text {trreatment }}$ represent the optical density of the blank control and the treatment at time $t . N_{0}$ represents the initial optical density. The medium effective concentration (EC50) inhibiting 50\% the biomass at time $t$ was calculated by fitting $P_{1}$ and ethyl cinnamate concentration with a linear regression.

(2) Chlorophyll Fluorescence Analysis. In this study, chlorophyll fluorescence was used to measure the photosynthetic activity of Chlorella vulgaris. Values of chlorophyll fluorescence are related with the switch state of reaction center of PSII. Chlorophyll fluorescence cannot be detected from dead cells. Thus, chlorophyll fluorescence can be used as a probe to monitor the photosynthesis of C. vulgaris.

The parameters, including $F_{0}$ (minimal fluorescence), $F_{m}$ (maximal fluorescence), and $\Phi_{\mathrm{PSII}}$ (actual photochemical efficiency of PSII in the light), were measured by MAXIImaging-PAM (Walz, Germany) after adaptation in the dark for $25 \mathrm{~min}$. The $F_{v} / F_{m}$ or $\left(F_{m}-F_{0}\right) / F_{m}$ (maximal photochemical efficiency of PSII) was obtained by calculation. What is noteworthy is that when algal cells are in normal state, the number of cells has little effect on $F_{v} / F_{m}$ and $\Phi_{\mathrm{PSII}}$.

The parameter, ETR (photosynthetic electron transport rate), can be calculated automatically by the instrument according to the formula as follows:

$$
\text { ETR }=\text { Yield } \times 0.84 \times 0.5 \times \text { PAR }
$$

Yield is actual photochemical efficiency of PSII in the light $\left(\Phi_{\text {PSII }}\right) ; 0.84$ is empirical constant (absorption rate of light from blade); 0.5 is due to photosynthetic system including two centers and electron transport in one center needing two photons; PAR is photosynthetically active radiation.

(3) Flow Cytometric Analysis. The flow cytometer BD FACSCalibur was used to measure the parameters of algal cells. The negative control (heat-treated cells at $100^{\circ} \mathrm{C}$ for $10 \mathrm{~min}$ ) was set before the experiments. Before the measurement, the voltage level of each detection channel was adjusted according to the fluorescent intensity of the heat-treated cells and normal cells, to make the fluorescent intensity of the normal algal cells in the middle level while reserving enough space for affected cells. And during the measurement, the voltage level was constant.

Fluorescein diacetate (FDA) was used to assess the esterase activities during the experiments $[30,35,37]$. The FDA (dissolved in acetone to a final concentration of $25 \mu \mathrm{mol} / \mathrm{L}$ ) stained the algal cells for $8 \mathrm{~min}$ in the dark, and then the fluorescence in the FLl channel $(515-545 \mathrm{~nm})$ was measured. An acetone control was added to eliminate effects resulting from acetone. The results demonstrated that acetone had no effect on the esterase activities of Chlorella vulgaris.

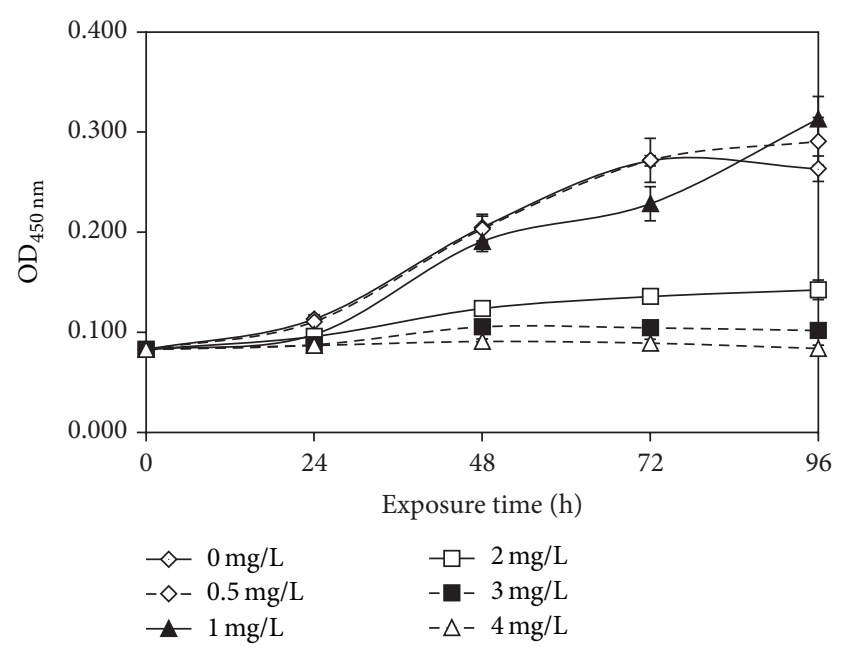

FIGURE 1: The effects of ethyl cinnamate on the biomass of Chlorella vulgaris. (The values represent the means \pm 1 standard deviation and $n=3$.)

Propidium iodide (PI) was used to assess the integrity of the cell membrane $[36,37,39]$. The PI (final concentration $10 \mu \mathrm{mol} / \mathrm{L}$ ) stained the algal cells for $15 \mathrm{~min}$ in the dark, and then the fluorescence in the FL2 channel $(564-606 \mathrm{~nm})$ was measured.

Cellular autofluorescence (chlorophyll a fluorescence) was detected in the FL3 channel $(>650 \mathrm{~nm})$ while measuring the FDA and PI staining fluorescence.

2.3. Data Analysis. Using Excel 2010 for statistical calculations, the results were expressed as the triplicate arithmetic mean \pm the standard deviation. ANOVA and two-factor analysis of variance were performed by SPSS 20.0. Significant difference levels were set to $0.05, p>0.05$, and $p<$ 0.05 , respectively, representing no significant difference and significant difference.

Summit 5.0 software was used for the data that was obtained by the flow cytometry, the fluorescent analysis of algal cells using histograms and the scatter plots. The fluorescent intensity in channel FL3 could help distinguish between algal cells and impurities to reduce the interference. To analyze the data, the Gate should be set in accordance with the fluorescent intensity in channel FL3, and the fluorescent intensity of the sample in the Gate could be used to calculate the mean fluorescent intensity of the algal cells (MFI) and the ratio of normal algal cells.

\section{Results and Discussion}

3.1. Growth Inhibition. The effects of ethyl cinnamate on the growth of Chlorella vulgaris are shown in Figure 1. After exposure to $0.5 \mathrm{mg} / \mathrm{L}$ ethyl cinnamate and a blank control for $96 \mathrm{~h}$, the biomass decreased compared with that after exposure for $72 \mathrm{~h}$. However, under the $1 \mathrm{mg} / \mathrm{L}$ ethyl cinnamate treatment, the biomass increased sustainably. The blank control and the $0.5 \mathrm{mg} / \mathrm{L}$ ethyl cinnamate treatment may have extra interference, possibly causing the biomass of $C$. vulgaris 


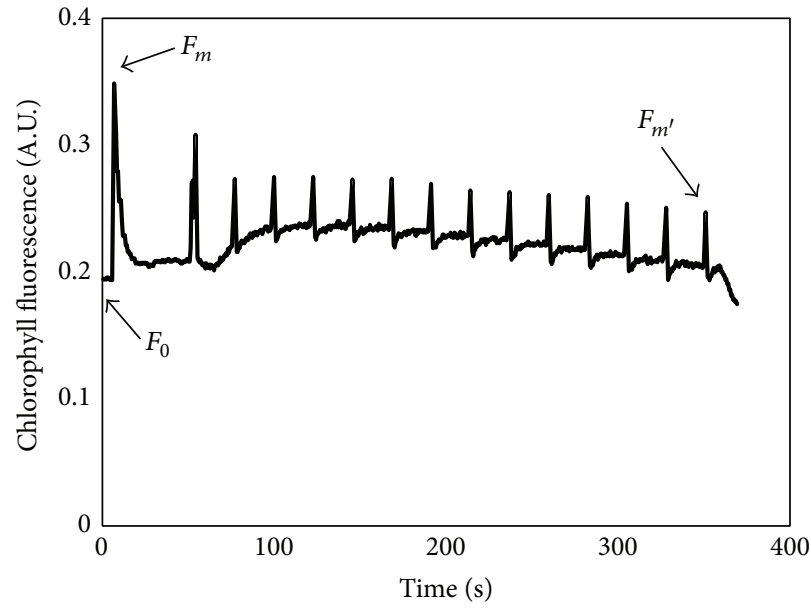

(a)

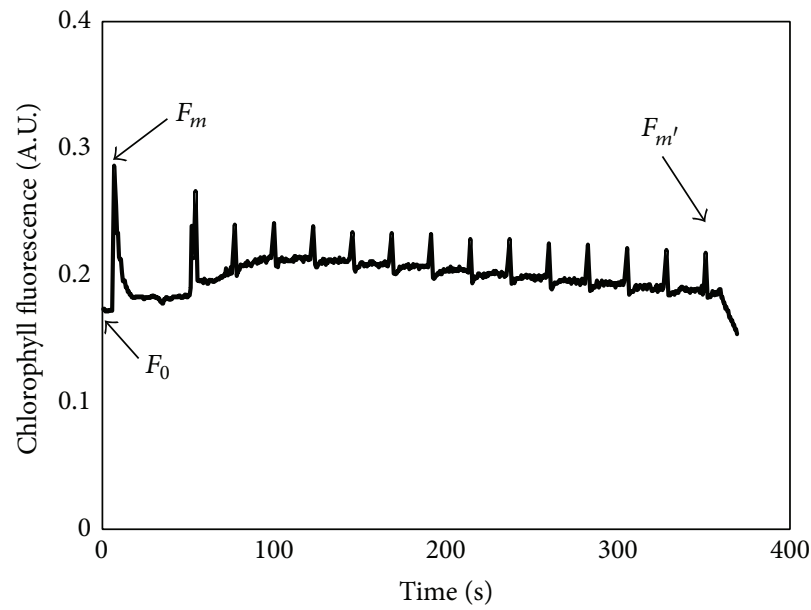

(c)

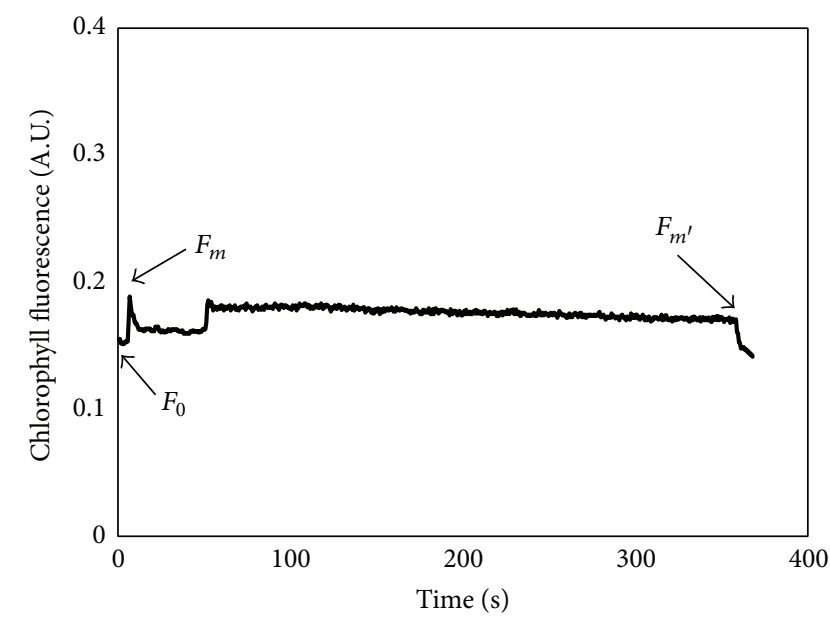

(e)

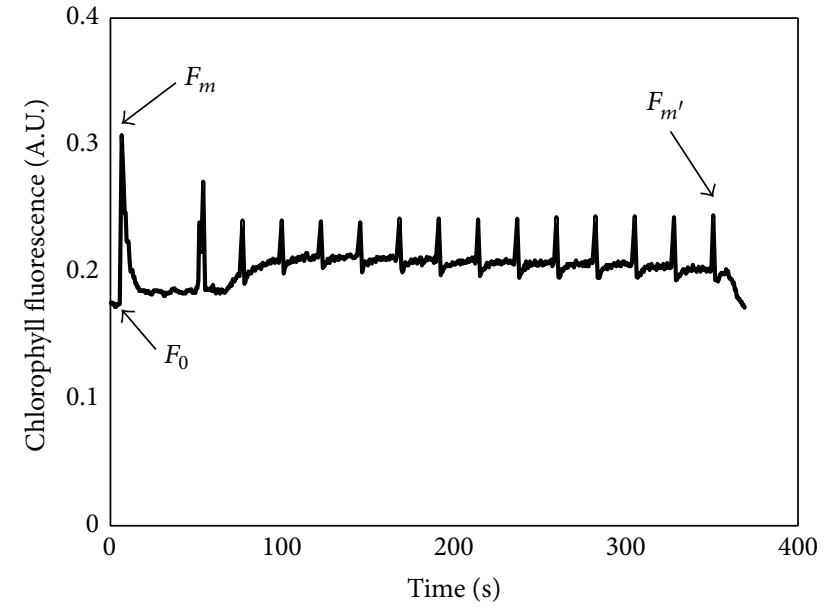

(b)

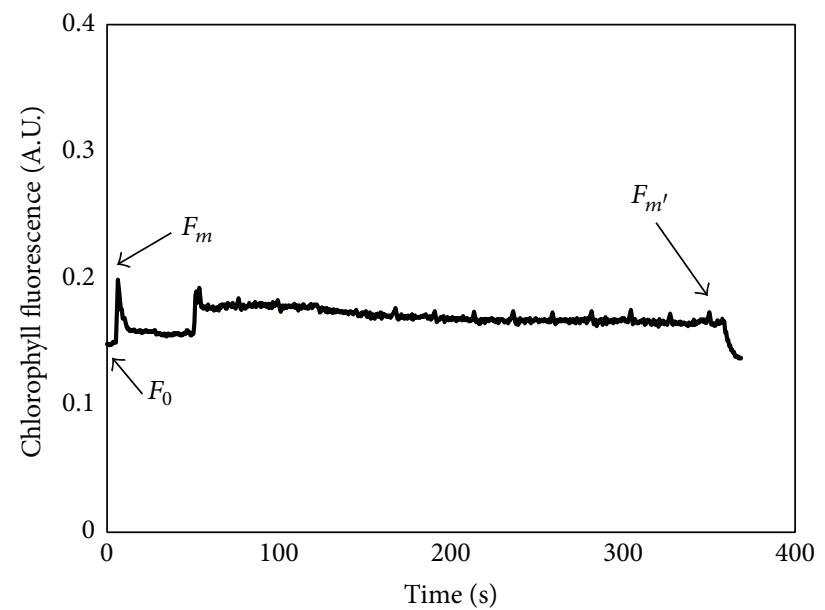

(d)

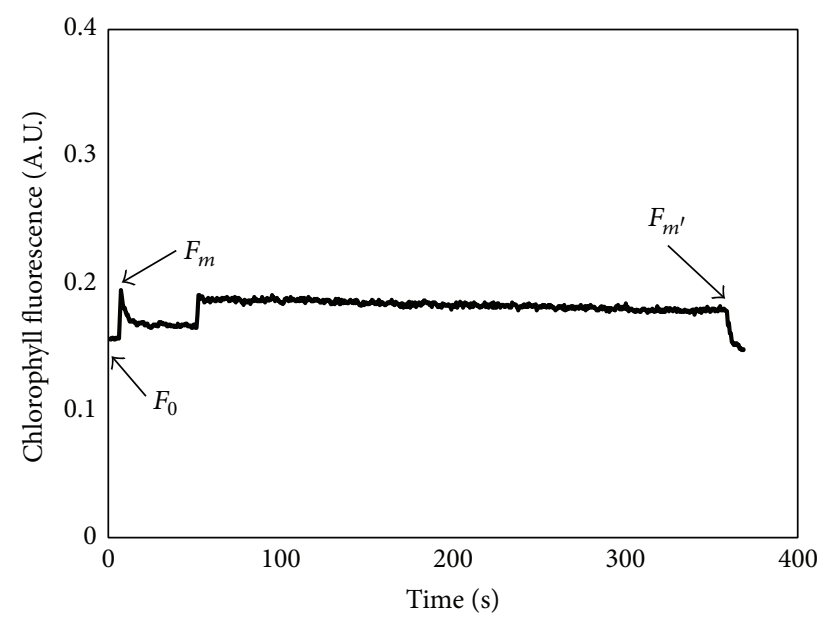

(f)

FIgURE 2: The photoinduced curves of Chlorella vulgaris after $24 \mathrm{~h}$ of exposure to ethyl cinnamate. ((a) Blank control, (b) $0.5 \mathrm{mg} / \mathrm{L}$ treatment, (c) $1 \mathrm{mg} / \mathrm{L}$ treatment, (d) $2 \mathrm{mg} / \mathrm{L}$ treatment, (e) $3 \mathrm{mg} / \mathrm{L}$ treatment, and (f) $4 \mathrm{mg} / \mathrm{L}$ treatment.) 


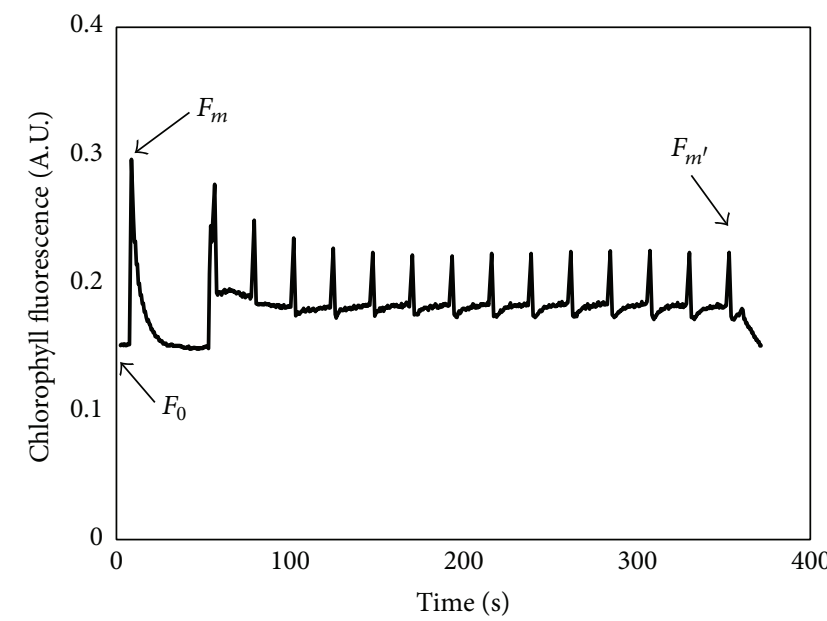

(a)

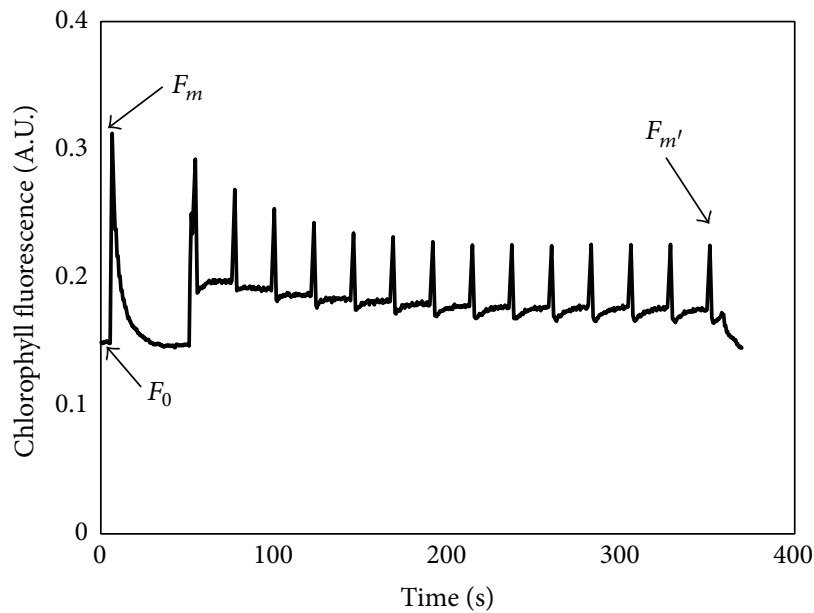

(c)

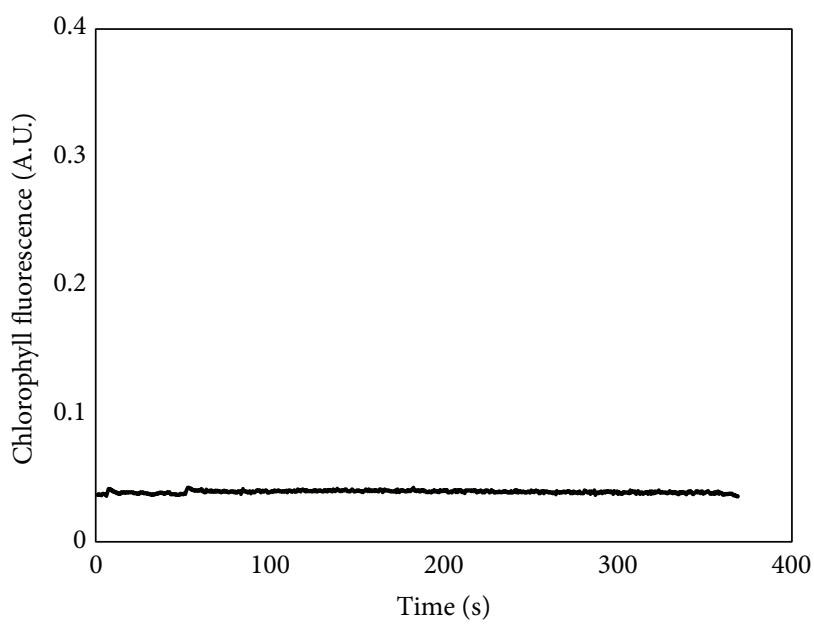

(e)

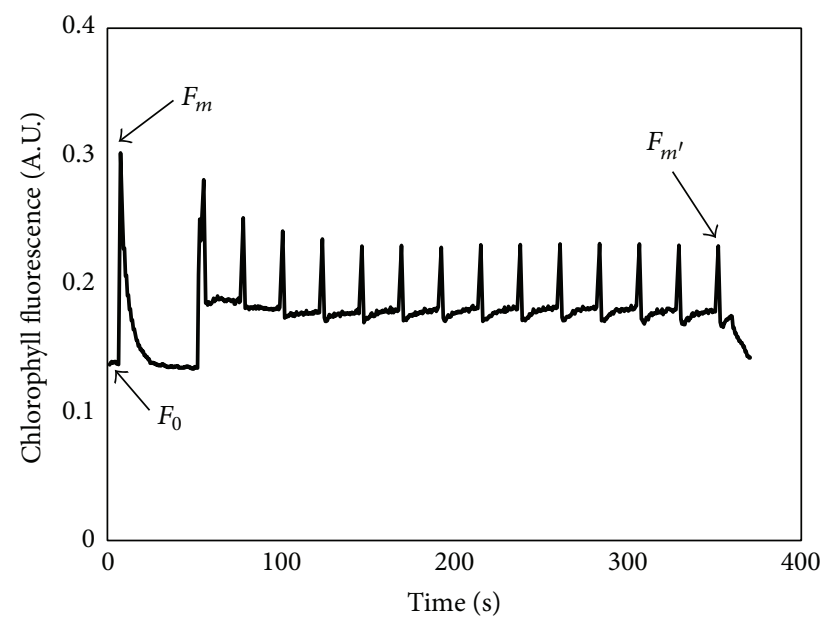

(b)

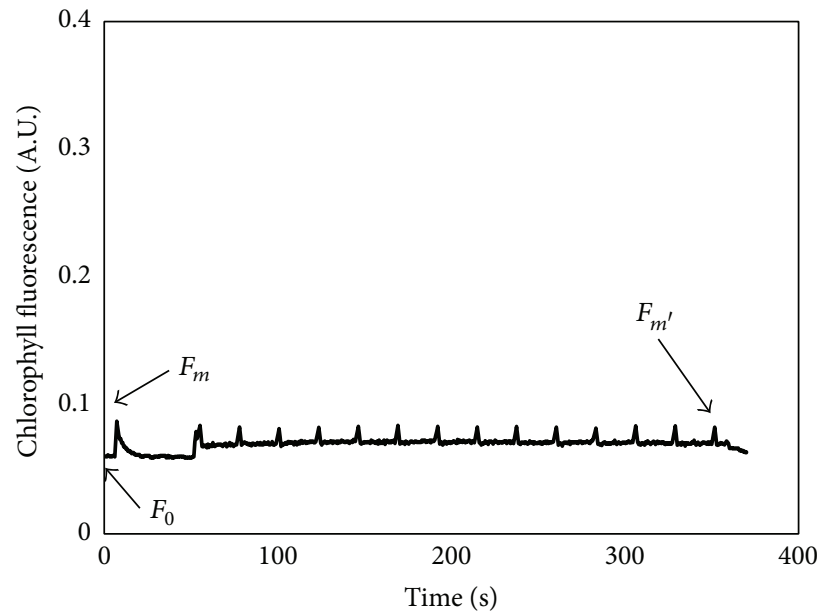

(d)

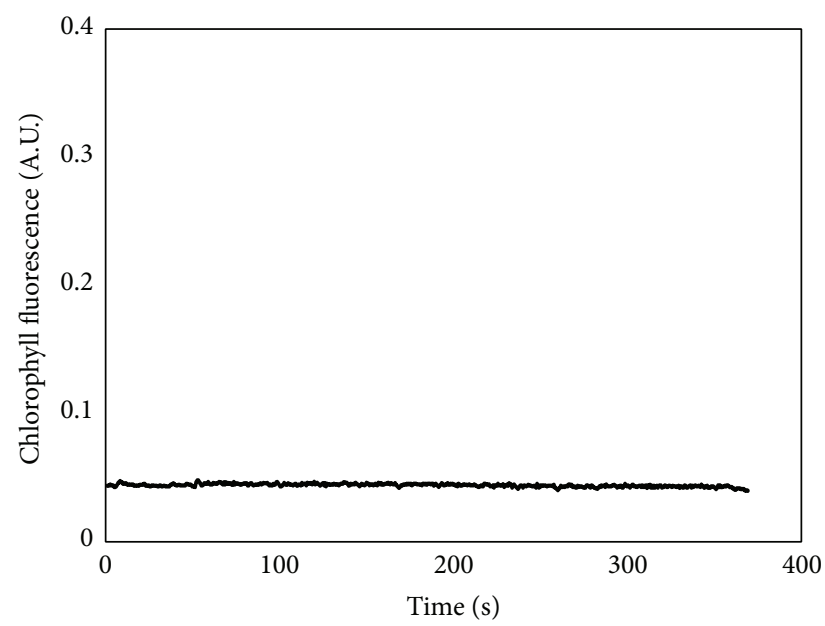

(f)

FIGURE 3: The photoinduced curves of Chlorella vulgaris after $96 \mathrm{~h}$ of exposure to ethyl cinnamate. ((a) Blank control, (b) $0.5 \mathrm{mg} / \mathrm{L}$ treatment, (c) $1 \mathrm{mg} / \mathrm{L}$ treatment, (d) $2 \mathrm{mg} / \mathrm{L}$ treatment, (e) $3 \mathrm{mg} / \mathrm{L}$ treatment, and (f) $4 \mathrm{mg} / \mathrm{L}$ treatment.) 
to be stagnant or even suppressed. As a consequence, after $72 \mathrm{~h}, 0.5 \mathrm{mg} / \mathrm{L}$ ethyl cinnamate had no significant effect on the biomass of $C$. vulgaris $(p>0.05)$. However, with the increasing concentrations of ethyl cinnamate, the degree of algal cell yield inhibition gradually increased. The exposure concentrations, exposure duration, and interaction of the two factors significantly influenced the biomass of $C$. vulgaris $(p<0.05)$. The 48 -h and 72-h EC50 of ethyl cinnamate were $2.07 \mathrm{mg} / \mathrm{L}$ (1.94-2.20) and $1.89 \mathrm{mg} / \mathrm{L}$ (1.82-1.97).

The study results of Pinheiro et al. [40] on the effects of microcystin-LR (MC-LR) and cylindrospermopsin (CYN) (they are also regarded by some researchers as allelopathic substances) on C. vulgaris indicated that MC-LR and CYN at environmentally occurring concentrations were unable to affect negatively growth of $C$. vulgaris. This could be due to the fact that these molecules played roles other than allelopathy in natural ecosystems or the selectivity of allelochemicals.

3.2. Photosynthetic Toxicity. The photoinduced curves of Chlorella vulgaris after exposure to ethyl cinnamate for $24 \mathrm{~h}$ are shown in Figure 2. After exposure to the $0.5 \mathrm{mg} / \mathrm{L}$ ethyl cinnamate for $24 \mathrm{~h}$, the $F_{0}, F_{m}$, and $F_{m^{\prime}}$ decreased by $4.1 \%, 6.9 \%$, and $0.9 \%$, respectively (Figure $2(\mathrm{~b})$ ). The decrease degree of chlorophyll fluorescence increased with the concentration of ethyl cinnamate. When the concentration of ethyl cinnamate reached $2 \mathrm{mg} / \mathrm{L}$, the $F_{0}, F_{m}$, and $F_{m^{\prime}}$ decreased by $12.1 \%, 35.6 \%$, and $23.4 \%$, respectively. When the concentrations of ethyl cinnamate were more than $2 \mathrm{mg} / \mathrm{L}$, the chlorophyll fluorescence of $C$. vulgaris was significantly inhibited. Although there was potential for photosynthesis, the actual photosynthetic activities were low, with fluctuations of chlorophyll fluorescence curves close to 0 for specific performance (Figures 2(e) and 2(f)).

The photoinduced curves of C. vulgaris under the blank control and ethyl cinnamate treatment after $96 \mathrm{~h}$ are shown in Figure 3. $0.5 \mathrm{mg} / \mathrm{L}$ and $1 \mathrm{mg} / \mathrm{L}$ ethyl cinnamate had little impact on the chlorophyll fluorescence of C. vulgaris. Compared with those of blank control, the $F_{0}, F_{m}$, and $F_{m^{\prime}}$ of C. vulgaris exposed to $0.5 \mathrm{mg} / \mathrm{L}$ ethyl cinnamate decreased by $4.3 \%, 0.2 \%$, and $3.3 \%$, respectively. Although the $F_{0}$ of C. vulgaris under $1 \mathrm{mg} / \mathrm{L}$ treatments decreased by $3.2 \%$, the $F_{m}$ and $F_{m^{\prime}}$ increased by $4.9 \%$ and $1.3 \%$, respectively. The $2 \mathrm{mg} / \mathrm{L}$ ethyl cinnamate affected the chlorophyll fluorescence of $C$. vulgaris significantly, for $F_{0}, F_{m}$, and $F_{m^{\prime}}$ decreasing by $63.5 \%, 73.0 \%$, and $67.1 \%$, respectively. The photoinduced curves of $C$. vulgaris were nearly linear under the $3 \mathrm{mg} / \mathrm{L}$ and $4 \mathrm{mg} / \mathrm{L}$ treatments, indicating that photosynthesis was completely inhibited in these two treatment groups (Figures 3(e) and 3(f)).

The $F_{v} / F_{m}$ (maximal photochemical efficiency of PSII), $\Phi_{\text {PSII }}$ (actual photochemical efficiency of PSII in the light), ETR (photosynthetic electron transport rate), and chlorophyll a fluorescence were used to manifest the photosynthetic toxicity of ethyl cinnamate on C. vulgaris. Values of maximum photochemical efficiency $\left(F_{v} / F_{m}\right)$ reflect the potential quantum efficiency of PSII and the decline in values will be seen when plants are under stress [31]. As a consequence, $F_{v} / F_{m}$ could be a sensitive indicator for photosynthesis. Actual

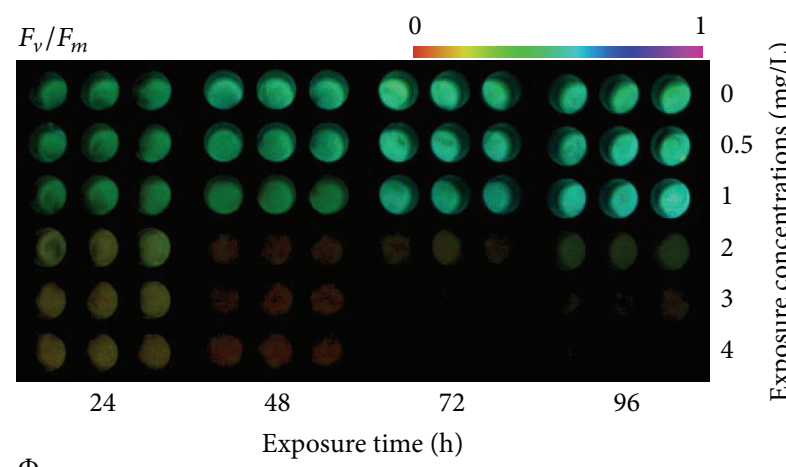

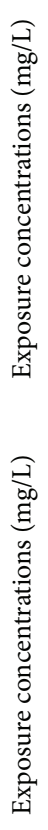

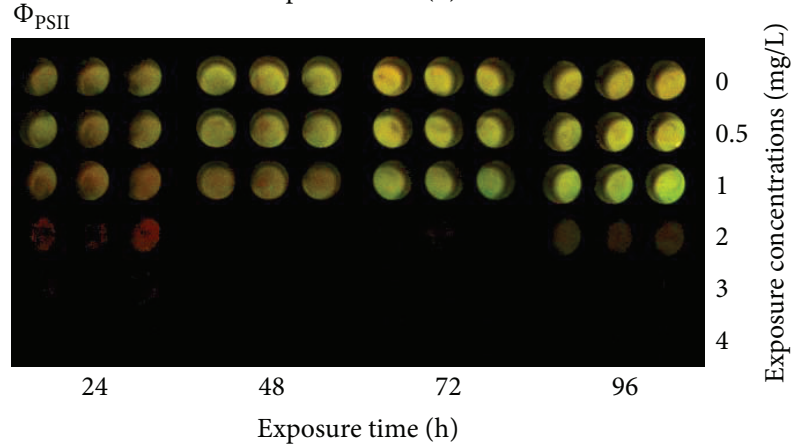

FIGURE 4: The fluorescent imaging of C. vulgaris under the stress of ethyl cinnamate.

photochemical efficiency measures the proportion of the light absorbed by chlorophyll associated with PSII that is used in photochemistry, also getting lower when plants are under stress [31]. In the experiment, the chlorophyll fluorescent imaging of C. vulgaris under the stress of ethyl cinnamate is shown in Figure 4 and the effects of ethyl cinnamate on the $F_{v} / F_{m}, \Phi_{\text {PSII }}$, and ETR of C. vulgaris are shown in Figure 5.

$0.5 \mathrm{mg} / \mathrm{L}$ ethyl cinnamate had little impact on the $F_{v} / F_{m}$ of C. vulgaris. Although $1 \mathrm{mg} / \mathrm{L}$ ethyl cinnamate affected the $F_{v} / F_{m}$ in the first $48 \mathrm{~h}$, there was no difference between the $F_{v} / F_{m}$ of blank control and that of the ethyl cinnamate treatment group after exposure for $72 \mathrm{~h}$ and $96 \mathrm{~h} .2-4 \mathrm{mg} / \mathrm{L}$ ethyl cinnamate significantly affected the $F_{v} / F_{m}$ of $C$. vulgaris, and the effects increased with the exposure concentration and time. After exposure to $4 \mathrm{mg} / \mathrm{L}$ ethyl cinnamate for $72 \mathrm{~h}$ and $96 \mathrm{~h}$, the photosynthesis of C. vulgaris was completely (100\%) inhibited.

Compared with the $F_{v} / F_{m}$, ethyl cinnamate inhibited the $\Phi_{\text {PSII }}$ and ETR of C. vulgaris much more. After exposure to $2 \mathrm{mg} / \mathrm{L}$ ethyl cinnamate for $24 \mathrm{~h}, \mathrm{C}$. vulgaris barely performed photosynthesis, with a slight recovery occurring after $96 \mathrm{~h}$. The $\Phi_{\text {PSII }}$ and ETR of $C$. vulgaris under the $3 \mathrm{mg} / \mathrm{L}$ and $4 \mathrm{mg} / \mathrm{L}$ ethyl cinnamate treatments were 0 during the entire exposure process.

Chlorophyll a fluorescence reflects chlorophyll a concentration. The decrease of values of chlorophyll a fluorescence often indicates that the photosynthesis of plants is inhibited. This parameter could also be a sensitive indicator for photosynthesis. Regarding the ratio of normal fluorescent cells, $0.5-4 \mathrm{mg} / \mathrm{L}$ ethyl cinnamate had no significant impact on the FL3 fluorescence (the autofluorescence of chlorophyll a) $(p>$ 0.05 ) but affected the mean FL3 fluorescence (the mean of 


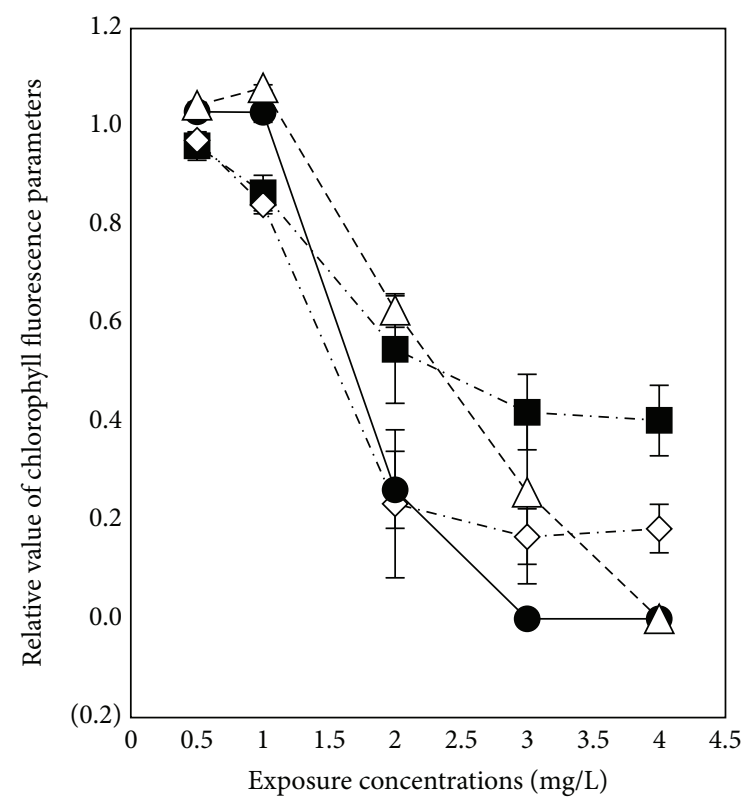

(a)

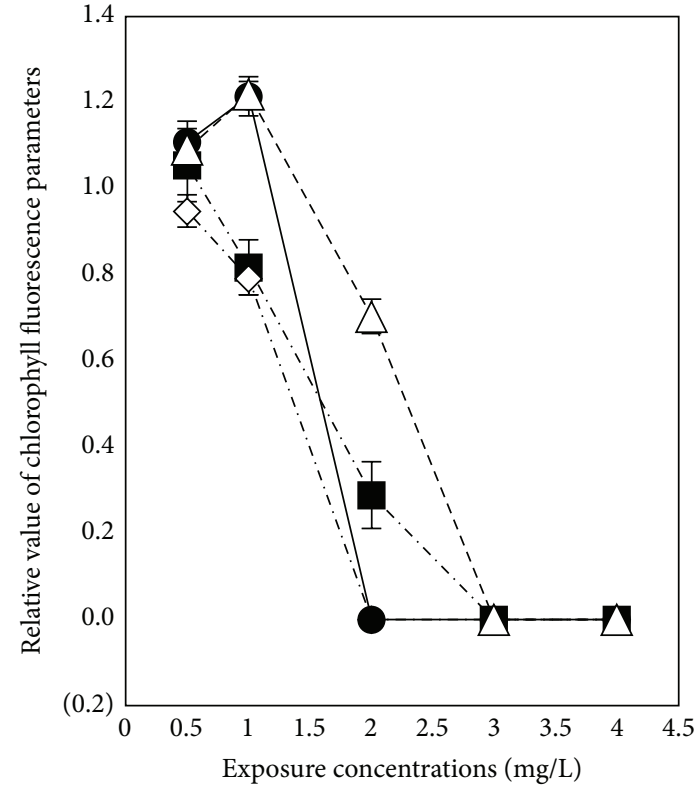

(b)

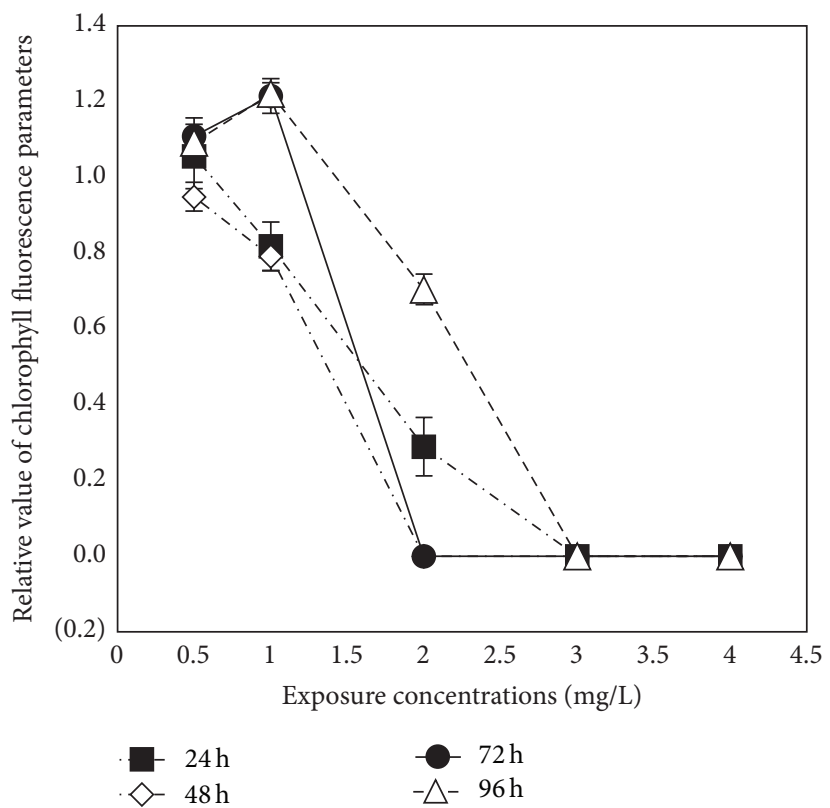

(c)

FIGURE 5: The effects of ethyl cinnamate on the $F_{v} / F_{m}, \Phi_{\mathrm{PSII}}$, and ETR of $C$. vulgaris. ((a) $F_{v} / F_{m}$; (b) $\Phi_{\mathrm{PSII}}$; (c) ETR.) (The relative value of chlorophyll fluorescence parameters: treatment-to-blank control ratio of chlorophyll fluorescence parameters.)

FL3 fluorescence value for all tested algal cells) in the different treatment groups, as shown in Figure 6. Studies have shown that the inhibition of the electron acceptor of PSII reaction centers led to an increase in the chlorophyll a fluorescence $[41,42]$, while the inhibition of the electronic supply resulted in a decrease [41]. In this study, chlorophyll content did not reduce significantly (according to the measurement results of the fluorescence of chlorophyll a) and the photosynthetic activities were inhibited. Based on the results, it was speculated that ethyl cinnamate inhibited the photosynthetic rates of C. vulgaris mainly through electron transfer chain rather than the structure of the chloroplasts.

The study results of Gao et al. [26] on the effects of ethyl cinnamate on Chlorella pyrenoidosa revealed a decrease of chlorophyll a and inhibition of growth, consistent with the results in this study. The study results of Brückner et al. [43] on the effects of ragweed inflorescence extract on the growth of $C$. vulgaris and Chlamydomonas sp. showed the allelochemicals in the extract decreased chlorophyll a content of C. vulgaris significantly. In this study, ethyl cinnamate had 


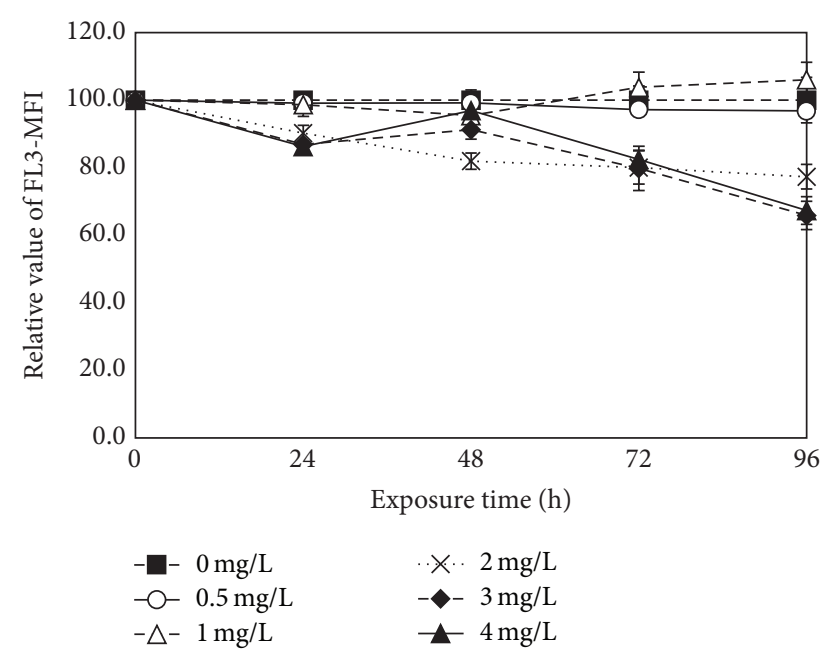

FIgURE 6: The effects of ethyl cinnamate on the fluorescence of chlorophyll a.

no significant impact on the FL3 fluorescence but affected the mean FL3 fluorescence, consistent with the results of Brückner et al. to some extent.

3.3. Cellular Physiological Toxicity. FDA and PI staining fluorescence, as well as FSC fluorescence, were measured to provide information in toxic effects of ethyl cinnamate on cellular physiology of Chlorella vulgaris. FDA staining fluorescence represents esterase activities of cells, and FDA only stains living cells. Thus, FDA staining fluorescence is a sensitive indicator for distinguishing between living cells and dead ones. Higher values of FDA staining fluorescence indicate higher esterase activities. Correspondingly, low values of FDA staining fluorescence mean low esterase activities; in other words, the cells are inhibited. The effects of ethyl cinnamate on the FDA staining fluorescence of Chlorella vulgaris are shown in Figure 7 . The blue area of the image represents the normal algal cells, the area of which can be used to calculate the ratio of normal fluorescent cells. The red area demonstrates that the esterase activities of $C$. vulgaris were affected; therefore, the FDA staining fluorescence is outside the normal range. The $0.5 \mathrm{mg} / \mathrm{L}$ and $1 \mathrm{mg} / \mathrm{L}$ ethyl cinnamate caused the ratio of normal fluorescent cells to be lower than that of the blank control; nevertheless, this ratio increased with the exposure time. After exposure for $96 \mathrm{~h}$, there were no prominent distinctions between the ratios of normal fluorescent cells of the blank control and that of the ethyl cinnamate treatment groups. Under the $2-4 \mathrm{mg} / \mathrm{L}$ ethyl cinnamate treatments, the ratios of algal cells of which the fluorescence was affected were much higher than normal cells. In addition, as the exposure time increased, so did the ratio of affected algal cells.

The effects of ethyl cinnamate on the esterase activities of C. vulgaris are shown in Figure 8. The $0.5-4 \mathrm{mg} / \mathrm{L}$ ethyl cinnamate treatments decreased the esterase activities of $C$. vulgaris, which could be observed even after $24 \mathrm{~h}$, indicating that both the ratios of normal fluorescent cells and the FL1MFI were lower than those of the blank control. In addition, the effects of ethyl cinnamate on the esterase activities of C. vulgaris were concentration-dependent. Under low ethyl cinnamate concentrations $(0.5$ and $1 \mathrm{mg} / \mathrm{L})$, as the exposure time increased, the degree of esterase activity inhibition decreased. The ratios of normal fluorescent cells were not much different from blank control after $96 \mathrm{~h}$; nevertheless, the FL1 fluorescence indicated that the esterase activities were still lower than blank control. Under high ethyl cinnamate concentrations $(2,3$, and $4 \mathrm{mg} / \mathrm{L})$, the degree of esterase activity inhibition increased with the exposure time, indicating that the ratios of normal fluorescent cells decreased continuously.

PI staining fluorescence could reflect in the integrity of the cell membrane, and PI only stains dead cells. As a result, the values of this parameter also represent mortality. High mortality means high values of PI staining fluorescence. From the results of PI staining, cells of C. vulgaris under treatment and blank control were in the same range, while no cells were found in the range of affected cells. This demonstrated that ethyl cinnamate had no significant effect on the integrity of the cell membrane of $C$. vulgaris (data not shown). Compared with the results in Section 3.1, it was possible that the effects of ethyl cinnamate on the growth of C. vulgaris were mainly the suppression of the agamogony. According to the study results of Gao et al. [26], ethyl cinnamate induced the overaccumulation of ROS and the increase of MDA, suggesting that ethyl cinnamate could lead to the damage of cell membrane system. However, according to this study, ethyl cinnamate had no significant effects on cell membrane integrity of $C$. vulgaris, demonstrating allelochemicals had diverse effects on different species of algae, in other words, selectivity. This perhaps also demonstrated Chlorella pyrenoidosa was more sensitive to allelochemicals.

The values of FSC fluorescence are relevant to the size of cells. The values of FSC fluorescence get higher with the size of cells being bigger. Ethyl cinnamate also significantly affected the size of the C. vulgaris cells. As shown in Figure 9, ethyl cinnamate increased the size of the C. vulgaris cells.

\section{Conclusions}

Ethyl cinnamate could significantly affect the growth, photosynthesis, and cellular physiology of Chlorella vulgaris. $1 \mathrm{mg} / \mathrm{L}$ ethyl cinnamate effectively inhibited the growth of $C$. vulgaris. The $48-\mathrm{h}$ and 72-h EC50 values were $2.07 \mathrm{mg} / \mathrm{L}$ (1.94-2.20) and $1.89 \mathrm{mg} / \mathrm{L}$ (1.82-1.97), respectively. Ethyl cinnamate significantly inhibited the $F_{v} / F_{m}$ of $C$. vulgaris at concentrations of 2,3 , and $4 \mathrm{mg} / \mathrm{L}$, with an even greater inhibition on the $\Phi_{\text {PSII }}$ and ETR. Based on the results, it was speculated that ethyl cinnamate inhibited the photosynthetic rate of $C$. vulgaris mainly through affecting the electron transfer chain rather than the structure of the chloroplasts. On individual cell basis, ethyl cinnamate decreased esterase activities in the cell but did not alter the integrality of cell membrane. It also resulted in increasing average cell size.

\section{Disclosure}

Hui-Ling Ouyang is the co-first author. 


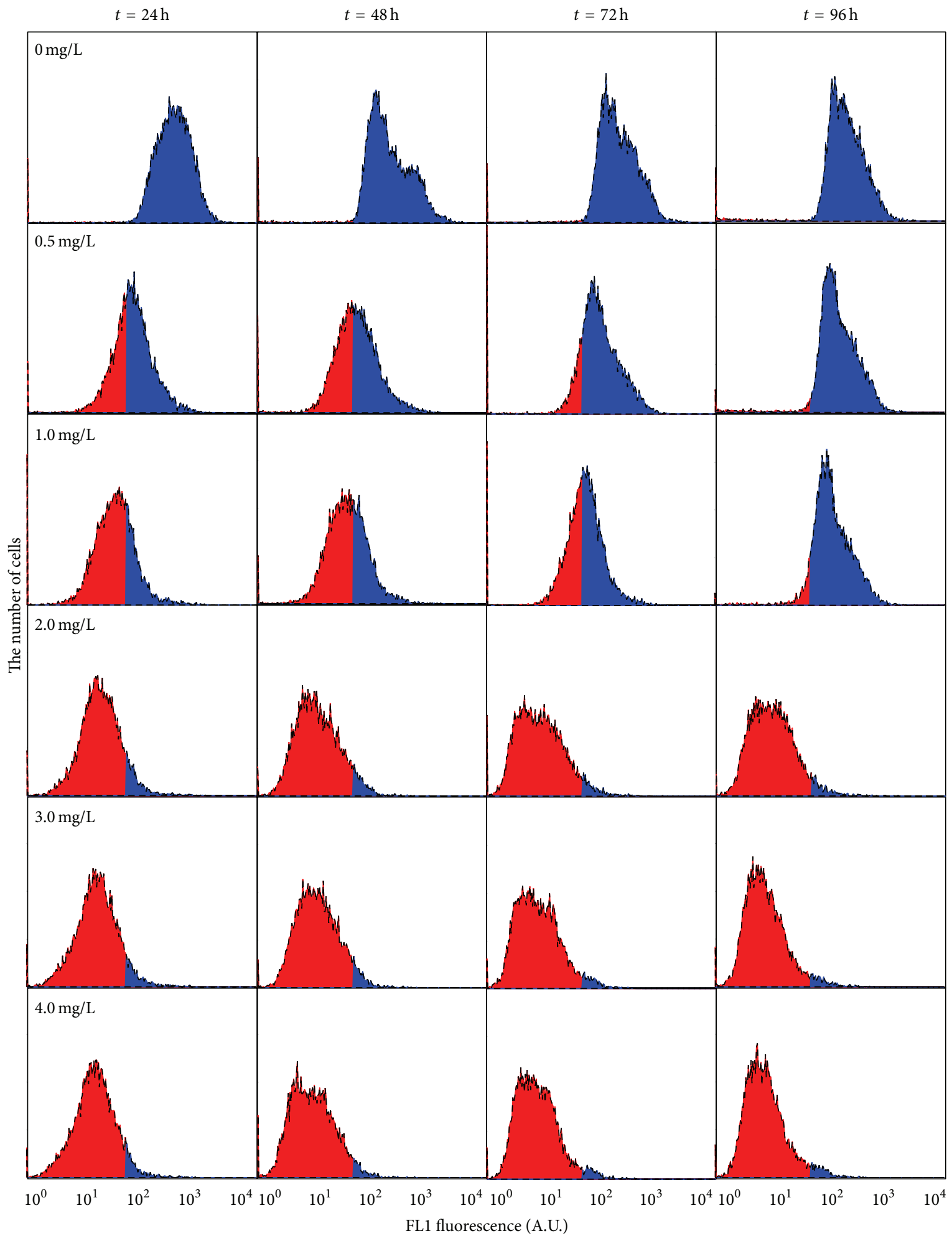

Figure 7: The effects of ethyl cinnamate on the FDA staining fluorescence of Chlorella vulgaris. 


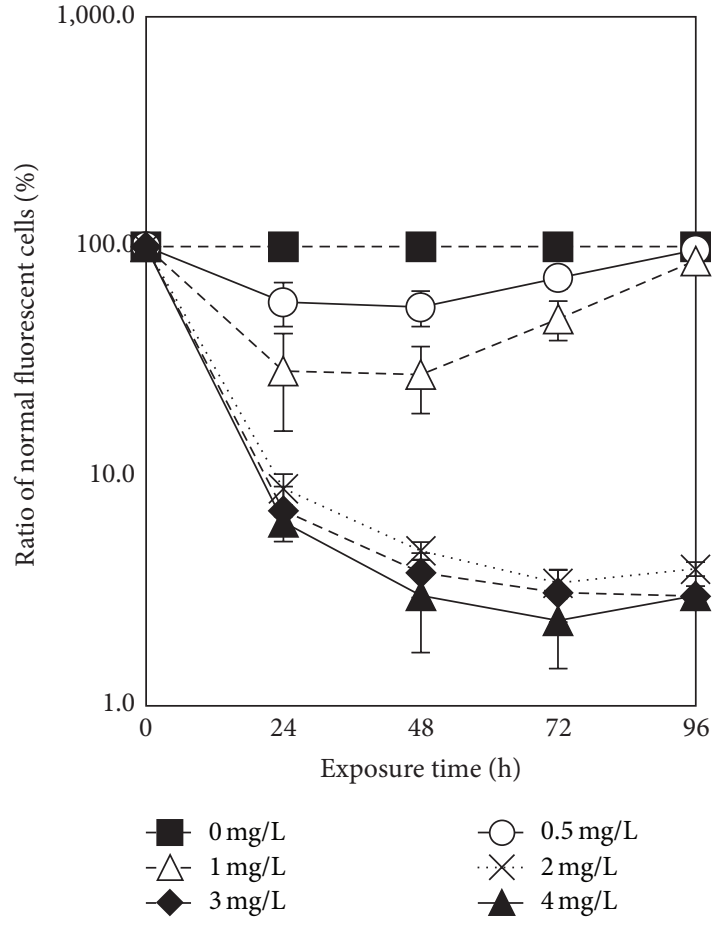

(a)

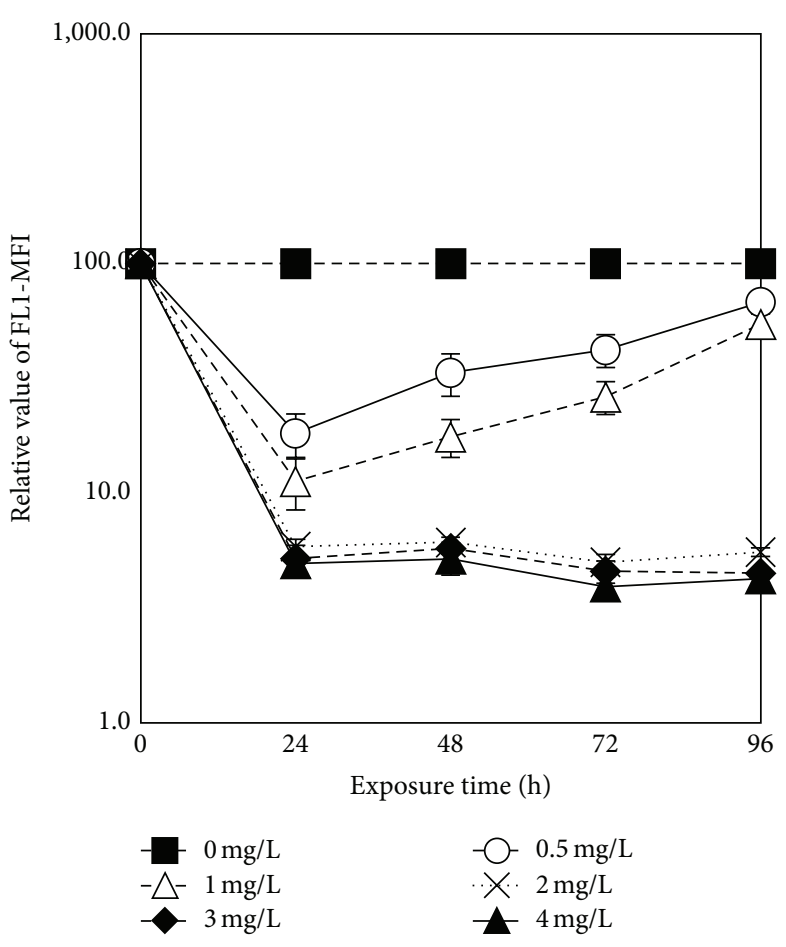

(b)

Figure 8: The effects of ethyl cinnamate on the esterase activities of C. vulgaris. ((a) The ratio of normal fluorescent cells and (b) the mean FL1 fluorescence.)

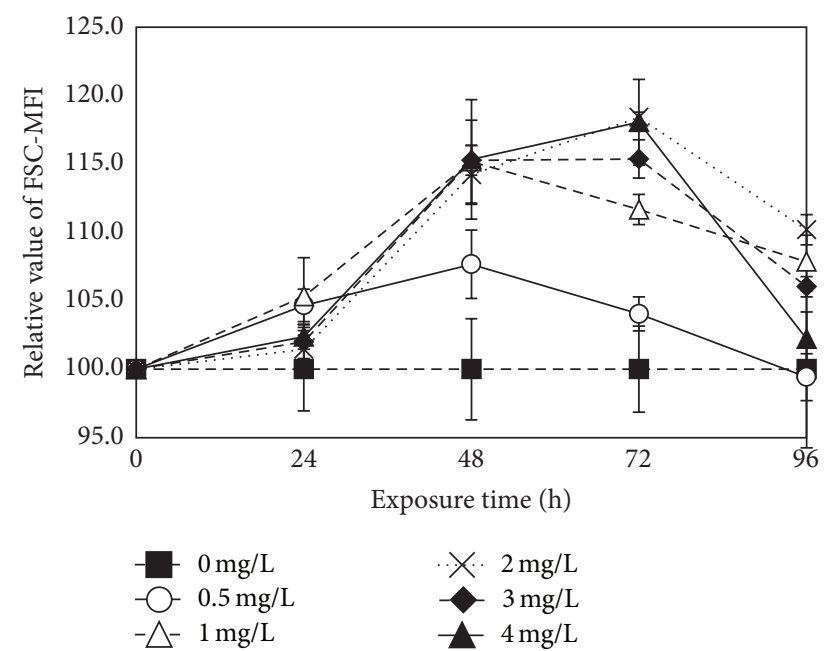

Figure 9: The effects of ethyl cinnamate on the size of the C. vulgaris cells.

\section{Conflict of Interests}

The authors declare that there is no conflict of interests regarding the publication of this paper.

\section{Acknowledgments}

The funding for this study was provided by National Project for Water Pollution Control (2012ZX07103-002) and the
National Science Foundation of China (NSFC) (41271462, 41030529). This work is also supported by a grant from the 111 Project (B14001), the undergraduate student research training program of the Ministry of Education, and Mao Yugang Undergraduate Research Grant, Peking University.

\section{References}

[1] Y.-J. Jiang, W. He, W.-X. Liu et al., “The seasonal and spatial variations of phytoplankton community and their correlation with environmental factors in a large eutrophic Chinese lake (Lake Chaohu)," Ecological Indicators, vol. 40, pp. 58-67, 2014.

[2] H. L. Ouyang, X. Z. Kong, W. He et al., "Effects of five heavy metals at sub-lethal concentrations on the reproduction and photosynthesis of Chlorella vulgaris," Chinese Science Bulletin, vol. 57, no. 10, pp. 785-793, 2012.

[3] H. L. Ou-Yang, X. Z. Kong, M. Lavoie et al., "Photosynthetic and cellular toxicity of cadmium in Chlorella vulgaris," Environmental Toxicology and Chemistry, vol. 32, no. 12, pp. 2762-2770, 2013.

[4] F. L. Xu, "Exergy and structural exergy as ecological indicators for the development state of the Lake Chaohu ecosystem," Ecological Modelling, vol. 99, no. 1, pp. 41-49, 1997.

[5] Y. C. Wang and K. H. Lu, "The harm of cyanobacterial blooms and governance," Chinese Journal of Fisheries, vol. 17, no. 1, pp. 90-93, 2004.

[6] H. Y. Hu, Y. J. Men, and F. M. Li, "Review on inhibition of plant allelopathy of algae reproduction," Ecology and Environment, vol. 15, no. 1, pp. 153-157, 2006. 
[7] F. M. Li and H. Y. Hu, "Mechanism of phyto-allelochemicals and its application for harmful algae control in nature water body," Water \& Wastewater Engineering, vol. 30, no. 2, pp. 1-4, 2004.

[8] E. L. Rice, Allelopathy, Academic Press, London, UK, 2nd edition, 1984.

[9] E. M. Gross, D. Erhard, and E. Iványi, "Allelopathic activity of Ceratophyllum demersum L. and Najas marina ssp. intermedia (Wolfgang) Casper," Hydrobiologia, vol. 506-509, no. 1-3, pp. 583-589, 2003.

[10] S. Nakai, Y. Inoue, and M. Hosomi, "Algal reproduction inhibition effects and inducement modes by plant-producing phenols," Water Research, vol. 35, no. 7, pp. 1855-1859, 2001.

[11] H. Kato-Noguchi, "Allelopathic substances in Pueraria thunbergiana," Phytochemistry, vol. 63, no. 5, pp. 577-580, 2003.

[12] N. T. Doan, R. W. Rickards, J. M. Rothschild, and G. D. Smith, "Allelopathic actions of the alkaloid 12-epi-hapalindole E isonitrile and calothrixin A from cyanobacteria of the genera Fischerella and Calothrix," Journal of Applied Phycology, vol. 12, no. 3-5, pp. 409-416, 2000.

[13] T. Igarashi, M. Satake, and T. Yasumoto, "Prymnesin-2: a potent ichthyotoxic and hemolytic glycoside isolated from the red tide alga Prymnesium parvum," Journal of the American Chemical Society, vol. 118, no. 2, pp. 479-480, 1996.

[14] K. D. Kearns and M. D. Hunter, "Toxin-producing Anabaena flos-aquae induces settling of Chlamydomonas reinhardtii, a competing motile alga," Microbial Ecology, vol. 42, no. 1, pp. 8086, 2001.

[15] R. Pratt and J. Fong, "Studies on Chlorella vulgaris II. Further evidence that Chlorella cells form a reproduction-inhibiting substance," American Journal of Botany, vol. 27, pp. 431-436, 1940.

[16] C. K. Schmitt, K. C. Meysick, and A. D. O'Brien, "Bacterial toxins: friends or foes?” Emerging Infectious Diseases, vol. 5, no. 2, pp. 224-234, 1999.

[17] G. D. Smith and N. T. Doan, "Cyanobacterial metabolites with bioactivity against photosynthesis in cyanobacteria, algae and higher plants," Journal of Applied Phycology, vol. 11, no. 4, pp. 337-344, 1999.

[18] S. Suikkanen, G. O. Fistarol, and E. Granéli, "Effects of cyanobacterial allelochemicals on a natural plankton community," Marine Ecology Progress Series, vol. 287, pp. 1-9, 2005.

[19] S. Suikkanen, J. Engström-Öst, J. Jokela, K. Sivonen, and M. Viitasalo, "Allelopathy of Baltic Sea cyanobacteria: no evidence for the role of nodularin," Journal of Plankton Research, vol. 28, no. 6, pp. 543-550, 2006.

[20] T. Yasumoto, B. Underdal, T. Aune, V. Hormazabal, O. M. Skulberg, and Y. Oshima, "Screening for hemolytic and ichthyotoxic components of Chrysochromulina polylepis and Gyrodinium aureolum from Norwegian coastal waters," in Toxic Marine Phytoplankton, pp. 436-440, Elsevier, New York, NY, USA, 1990.

[21] S. Körner and A. Nicklisch, "Allelopathic growth inhibition of selected phytoplankton species by submerged macrophytes," Journal of Phycology, vol. 38, no. 5, pp. 862-871, 2002.

[22] G. Mulderij, E. van Donk, and J. G. M. Roelofs, "Differential sensitivity of green algae to allelopathic substances from Chara," Hydrobiologia, vol. 491, no. 1-3, pp. 261-271, 2003.

[23] K. K. Schrader, N. P. Dhammika Nanayakkara, C. S. Tucker, A. M. Rimando, M. Ganzera, and B. T. Schaneberg, "Novel derivatives of 9,10-anthraquinone are selective algicides against the musty-odor cyanobacterium Oscillatoria perornata," Applied and Environmental Microbiology, vol. 69, no. 9, pp. 5319-5327, 2003.

[24] X.-X. Sun, J.-K. Choi, and E.-K. Kim, "A preliminary study on the mechanism of harmful algal bloom mitigation by use of sophorolipid treatment," Journal of Experimental Marine Biology and Ecology, vol. 304, no. 1, pp. 35-49, 2004.

[25] G. G. Bian, "Review on inhibition of terrestrial plant allelopathy of algae reproduction," Environmental Science \& Technology, vol. 35, no. 2, pp. 90-95, 2012.

[26] L. L. Gao, P. Y. Guo, G. M. Su, and Y. F. Wei, "Effects of allelochemicals ethyl cinnamate on the growth and physiological characteristics of Chlorella pyrenoidosa," Environmental Science, vol. 34, no. 1, pp. 156-162, 2013.

[27] M. He, T. Zhang, A. Wu, and L. Nie, "Inhibition of cinnamic acid on Microcystis aeruginosa K. and Scenedesmus arcuatus L," Chinese Journal of Applied \& Environmental Biology, vol. 14, no. 6, pp. 774-778, 2008.

[28] K. K. Schrader, M. Q. De Regt, P. R. Tidwell, C. S. Tucker, and S. O. Duke, "Selective growth inhibition of the mustyodor producing Cyanobacterium Oscillatoria cf. chalybea by natural compounds," Bulletin of Environmental Contamination and Toxicology, vol. 60, no. 4, pp. 651-658, 1998.

[29] G. B. Williamson, E. M. Obee, and J. D. Weidenhamer, "Inhibition of Schizachyrium scoparium (poaceae) by the allelochemical hydrocinnamic acid," Journal of Chemical Ecology, vol. 18, no. 11, pp. 2095-2105, 1992.

[30] J. L. Stauber, N. M. Franklin, and M. S. Adams, "Applications of flow cytometry to ecotoxicity testing using microalgae," Trends in Biotechnology, vol. 20, no. 4, pp. 141-143, 2002.

[31] K. Maxwell and G. N. Johnson, "Chlorophyll fluorescence-a practical guide," Journal of Experimental Botany, vol. 51, no. 345, pp. 659-668, 2000.

[32] e. Govindjee, "Sixty-three years since Kautsky: chlorophyll a fluorescence," Australian Journal of Plant Physiology, vol. 22, no. 2, pp. 131-160, 1995.

[33] G. H. Krause, "Photoinhibition of photosynthesis. An evaluation of damaging and protective mechanisms," Physiologia Plantarum, vol. 74, no. 3, pp. 566-574, 1988.

[34] D. Lazár, "Chlorophyll a fluorescence induction," Biochimica et Biophysica Acta, vol. 1412, no. 1, pp. 1-28, 1999.

[35] N. M. Franklin, J. L. Stauber, and R. P. Lim, "Development of flow cytometry-based algal bioassays for assessing toxicity of copper in natural waters," Environmental Toxicology and Chemistry, vol. 20, no. 1, pp. 160-170, 2001.

[36] N. M. Franklin, M. S. Adams, J. L. Stauber, and R. P. Lim, "Development of an improved rapid enzyme inhibition bioassay with marine and freshwater microalgae using flow cytometry," Archives of Environmental Contamination and Toxicology, vol. 40, no. 4, pp. 469-480, 2001.

[37] Y. Yu, F. Kong, M. Wang, L. Qian, and X. Shi, "Determination of short-term copper toxicity in a multispecies microalgal population using flow cytometry," Ecotoxicology and Environmental Safety, vol. 66, no. 1, pp. 49-56, 2007.

[38] F. Li, G. Wu, S. Hu, Z. Fan, and Q. Gao, "Growth behavior and physiological characteristics of Chlorella vulgaris in the presence of deicing salt," Procedia Environmental Sciences, vol. 18, pp. 20-25, 2013.

[39] W. Liu, S. Chen, X. Quan, and Y.-H. Jin, "Toxic effect of serial perfluorosulfonic and perfluorocarboxylic acids on the membrane system of a freshwater alga measured by flow cytometry," Environmental Toxicology and Chemistry, vol. 27, no. 7, pp. 1597-1604, 2008. 
[40] C. Pinheiro, J. Azevedo, A. Campos, S. Loureiro, and V. Vasconcelos, "Absence of negative allelopathic effects of cylindrospermopsin and microcystin-LR on selected marine and freshwater phytoplankton species," Hydrobiologia, vol. 705, no. 1, pp. 27-42, 2013.

[41] G. Samson, J. Claude Morisette, and R. Popovic, "Copper quenching of the variable fluorescence in Dunaliella tertiolecta. New evidence for a copper inhibition effect on PSII photochemistry," Photochemistry and Photobiology, vol. 48, no. 3, pp. 329332, 1988.

[42] I. Yruela, M. Alfonso, I. O. De Zarate, G. Montoya, and R. Picorel, "Precise location of the $\mathrm{Cu}(\mathrm{II})$-inhibitory binding site in higher plant and bacterial photosynthetic reaction centers as probed by light-induced absorption changes," The Journal of Biological Chemistry, vol. 268, no. 3, pp. 1684-1689, 1993.

[43] D. J. Brückner, A. Lepossa, and Z. Herpai, "Inhibitory effect of ragweed (Ambrosia artemisiifolia L.)-inflorescence extract on the germination of Amaranthus hypochondriacus L. and growth of two soil algae," Chemosphere, vol. 51, no. 6, pp. 515-519, 2003. 

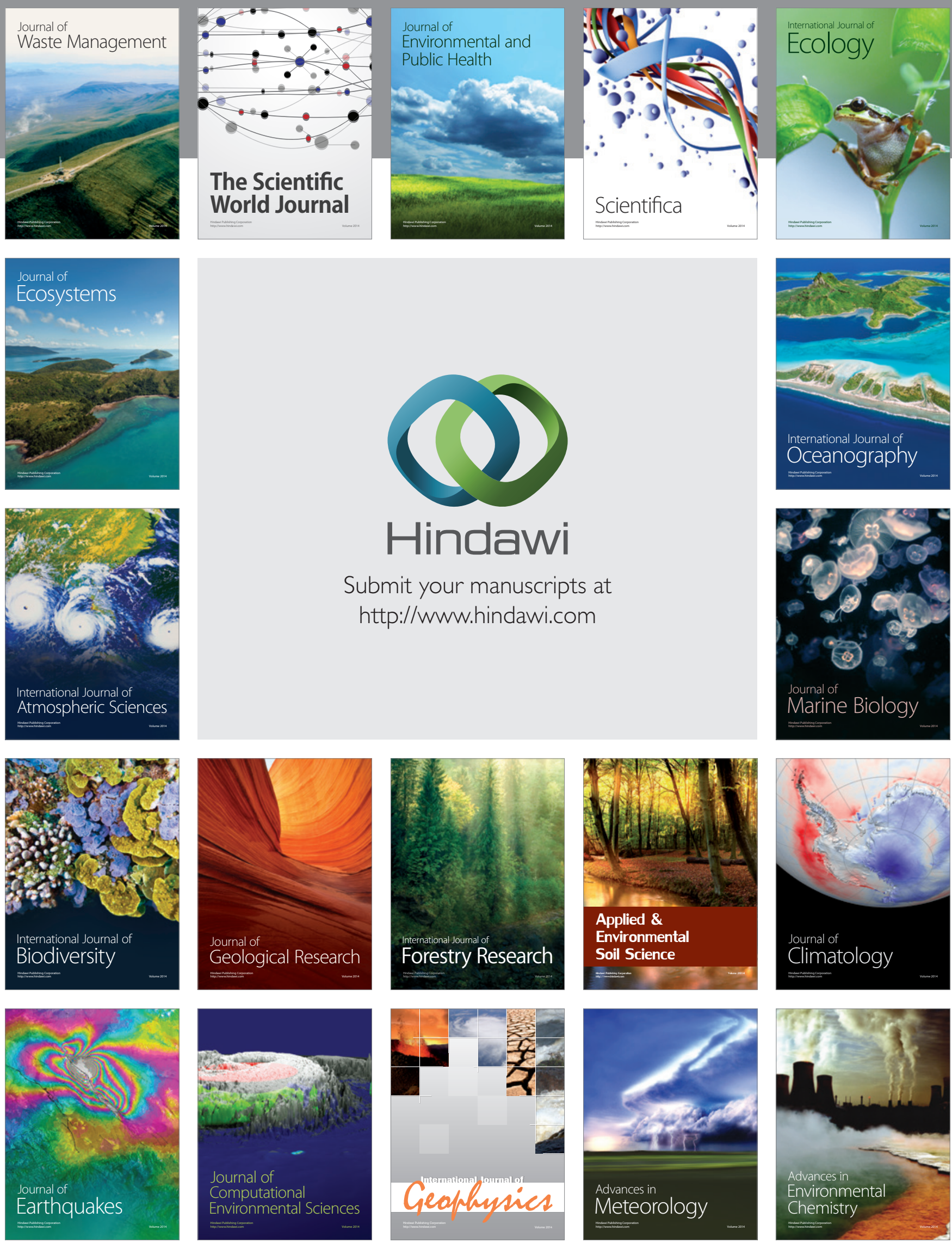